\title{
Rat-Bite Fever
}

National Cancer Institute

\section{Source}

National Cancer Institute. Rat-Bite Fever. NCI Thesaurus. Code C34971.

An infectious disease that is caused transmitted by the bite of a rat. Two species of bacteria can cause the infection: Streptobacillus moniliformis and Spirillum minus. 